\title{
BEHAVIOR AT A NEST OF AMAZILIA LACTEA (AVES, TROCHILIDAE)
}

\author{
Yoshika Oniki ${ }^{1}$ \\ Alexsander Z. Antunes ${ }^{1}$ \\ Edwin O. Willis ${ }^{1}$
}

\begin{abstract}
The hummingbird Amazilia lactea (Lesson, 1832) built a nest in São Paulo, Brazil, in the spring (Oct) and added lichens during incubation. The female incubated over 70 per cent of the day, 1-56 min per visit, and brooded two small young somewhat less; brooding stopped by about 10 days of age, as did night brooding. Lack of night brooding for large young hummingbirds may reflect lack of space in a small nest. Young stayed in the nest 19 days. Feedings were widely spaced, and presence of possible predators caused alarm.
\end{abstract}

KEYWORDS. Amazilia lactea, nest, behavior, Brazil.

\section{INTRODUCTION}

The Sapphire-spangled Emerald Amazilia lactea (Lesson, 1832), Trochilidae is a small hummingbird, some $9-10 \mathrm{~cm}$ long $(4.27 \pm 0.43 \mathrm{~g}$, range $3.5-5.2, \mathrm{n}=59)$ that frequents gardens and yards at edges of towns and low to high levels of forest edges and second growth, from Venezuela to southeast Brazil. It favors such bright red flowers as the exotic Malvaviscus arboreus Cavanilles (Malvaceae), used as decoration of yards or as natural fences, but visits many other species (pers. obs.).

IHERING (1900) reported a cup nest of $A$. lacta, $4 \mathrm{~cm}$ tall and wide, internal diameter $2 \mathrm{~cm}$; plant down with bits of "bark" outside, egg 13.5 x $8 \mathrm{~mm}$. NieTHAMmer (1953) photographed a nest $2 \mathrm{~m}$ in a papaya shrub, September, with 2 small young holding on to the nest lining (eggshells still present); internal diameter $2.5 \mathrm{~cm}$, depth $2 \mathrm{~cm} ; 40 \mathrm{~min}$ between feedings, the female hovering backward to leave with a triple note. RuscHI $(1949,1982)$ also reports nests. Here we report on behavior at a nest on the campus of the Universidade Estadual Paulista, Rio Claro, São Paulo, Brazil and, also report on other nests.

1. Departamento de Zoologia, Universidade Estadual Paulista, Caixa Postal 199, CEP 13506-900 Rio Claro, SP, Brazil. 


\section{MATERIAL AND METHODS}

The campus of the Universidade Estadual Paulista (UNESP) (620 m elevation, $22^{\circ} 23^{\prime} \mathrm{S}, 47^{\circ} 33^{\prime} \mathrm{W}$ ), with many buildings, has scattered trees and bushes. Observations at the nest started on 17 Oct 1993 for a total of 125 h 24 min, ending on 26 Nov 1993, when the nest was collected and deposited in the Museu de Ciências da Natureza, UNESP, Rio Claro. We observed for only 10 min each on 4, 10, 19, 22, 23, 24 and 25 Nov; 35 min on 26 Nov but on 24, 29, 30, 31 Oct, 1, 2, 5, 6, 7, 13, 14, 15, 17, 20, 21 Nov, we observed an average of $494.14 \mathrm{~min} /$ day (range $105-732 \mathrm{~min} /$ day).

We studied the nest with binoculars $9 \times 23$ and $8 \times 40$ from a distance of $8-10 \mathrm{~m}$, without blind. Usually one person was observing, at times two or three. Sketches of female and young in the nest (figs. 1-14) were made in the field. Plants were identified by A. Z. Antunes (UNESP).

\section{RESULTS AND DISCUSSION}

Nest Building and Incubation. The nest was on a vine (Ficus pumila L., Moraceae) $2.35 \mathrm{~m}$ up under a horizontal concrete bar of the Instituto de Biociências building, next to an interior sidewalk. On 17 Oct, the nest under construction was a shallow cup without lichens. Two days later (19 Oct), there were some whitish-green lichens on the outer walls. After two more days ( $21 \mathrm{Oct}, 17 \mathrm{~h} 58 \mathrm{~min})$, the female was first seen sitting on the nest, facing NW. Two white eggs were later present (29 Oct). The collected nest was 3.5 $\mathrm{cm}$ across by $2.5 \mathrm{~cm}$ high outside, 3.3 across by $1.6 \mathrm{~cm}$ deep inside. In Amazilia fimbriata (Gmelin, 1788) eggs are laid two days apart, and nest building continues during incubation (HAVERSCHMIDT, 1952).

The cup nest looked pale because of the inner down and the whitish green lichens outside, unlike a nest of Chlorostilbon aureoventris (Orbigny \& Lafresnaye, 1838) on the same campus (ONIKI \& ANTUNES, 1998), which was made of light colored down but had outer walls covered with thin brown bark strips. We found few bark strips on the outer walls of the A. lactea nest, unlike IHERING (1900).

The female incubated $71.2 \%$ of the day ( 24 Oct), with brief visits and absences ( 7 h 40 min- 8 h) when she pecked at lichens on the nest edge or added new ones as if building. At $8 \mathrm{~h}$, after putting a piece of lichen on the outer wall (figs. 1,2), she moved the body sideways and sat low with bill almost horizontal when it started to rain (figs. 3, 4). Even later in the day, she often brought new lichens. Five days later (29 Oct), she occasionally brought a lichen on return, or billed the nest edge as she sat, protruding the tongue 1 to 7 times. At $10 \mathrm{~h} 22 \mathrm{~min}$ she brought white plant down and added it to the bottom of the nest (as 3 times as on $31 \mathrm{Oct}$ ).

On 24 Oct, the female seemed to ignore cars or motorcycles $15 \mathrm{~m}$ off; occasionally she left when a bicyclist, person or cat passed near the nest. She left the nest to attack a Molothrus bonariensis (Gmelin, 1789) female on the ground, diving past it 3 times ( $9 \mathrm{~h}$ $45 \mathrm{~min}, 29 \mathrm{Oct})$. Seven days later, she flew from the nest on 3 occasions when a cat or cats passed. She mostly ignored A. lactea, Eupetomena macroura (Gmelin, 1788) and Chlorostilbon aureoventris in flowers or trees in the area. Once she attacked Troglodytes aedon Vieillot, 1807 on her return (1 Nov, 9 h $57 \mathrm{~min}$ ), and twice fled the nest when Pitangus sulphuratus (L., 1766) came to a guava tree (Psidium guajava L., Myrtaceae). She also fled the next day $(2 \mathrm{Nov})$; later $(13 \mathrm{~h})$, she watched it but stayed on the nest.

At times, she hovered below the nest and examined the under side of the concrete bar looking for insects. Once, she snapped up a large ant from the vine with a sharp "tchup!" call, then flew to the nest and settled. She could stretch her right wing and settle 

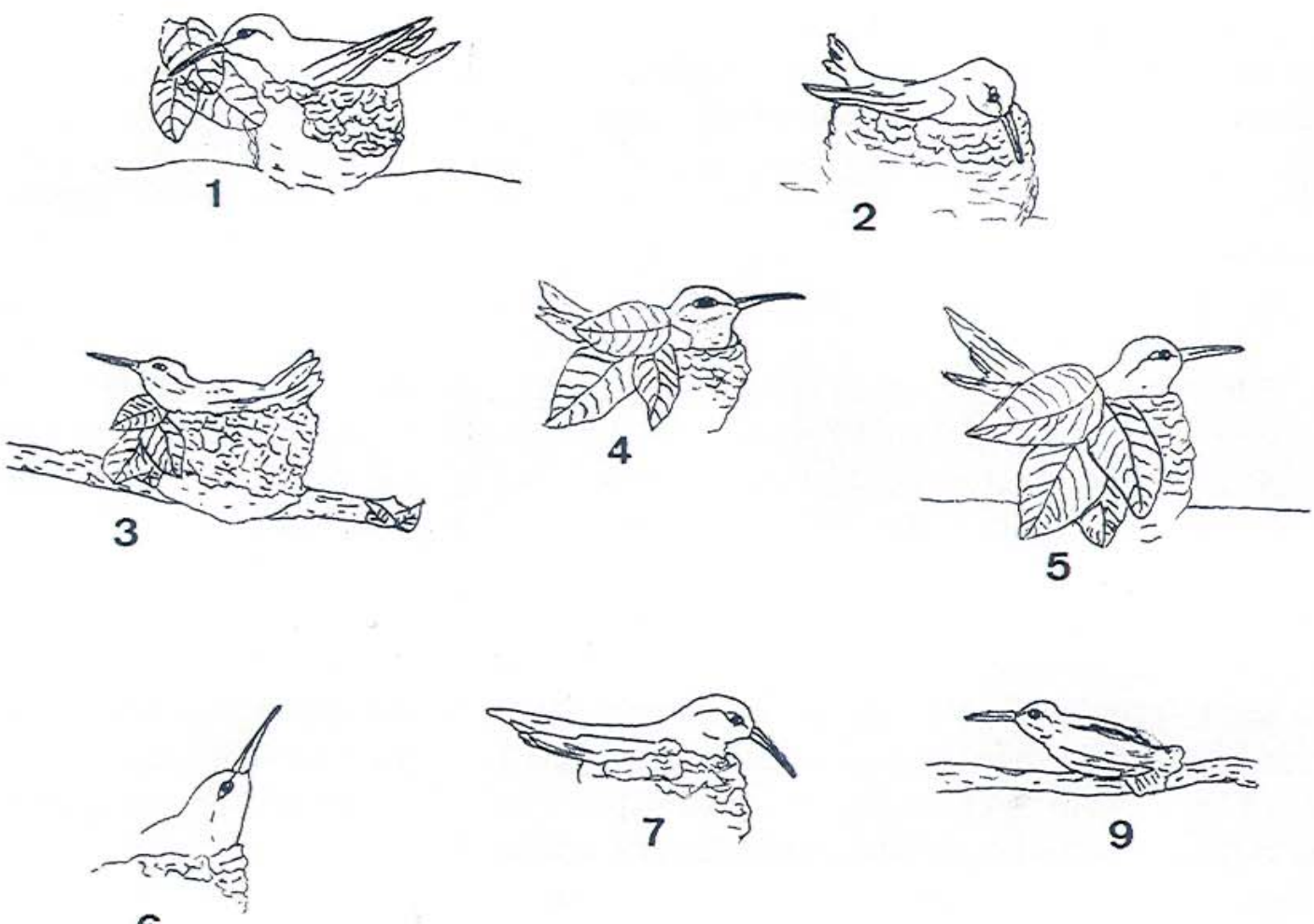

6

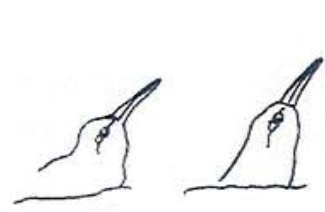

8
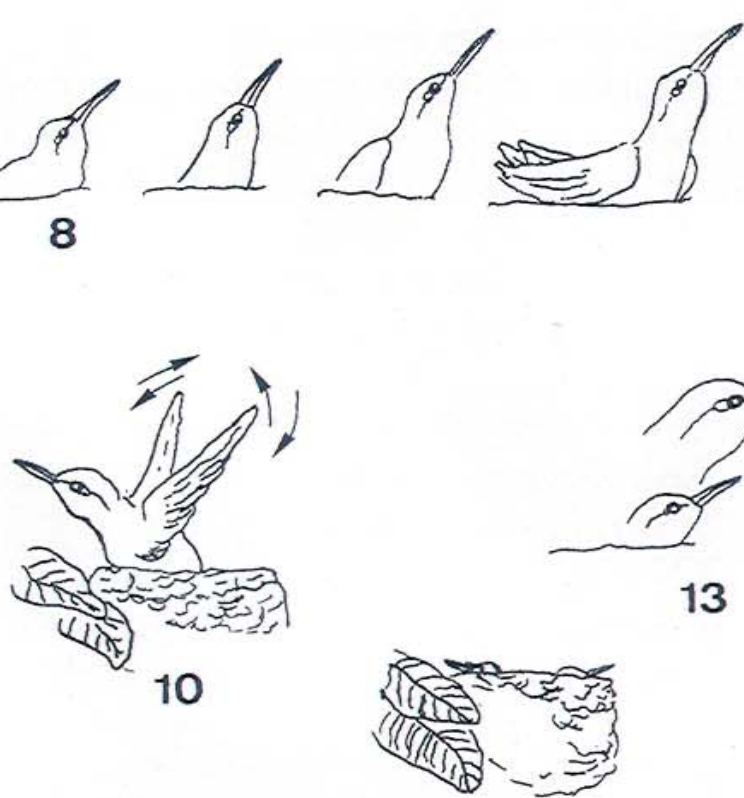

12

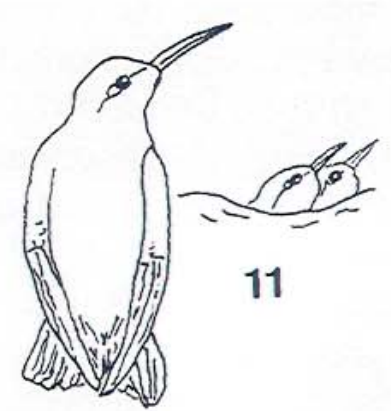

13

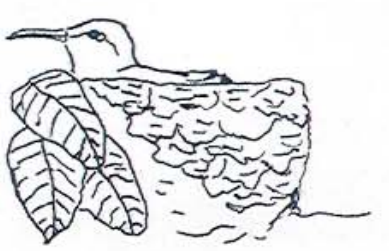

14

Figs. 1-14. Amazilia lactea: 1, 2, female tucking lichen on the outer wall of nest; 3, 4, incubating female sitting low during rain; 5 , female alert, just before leaving nest; 6 , female points bill up as she looks at something above; 7 , incubating female looks down at vine; 8 , female stretches neck a bit, then more, before hovering to get tiny insect in between leaves above, then back to nest; 9 , preening and sunning, with tail spread; 10, large young with body a bit raised, fluttering wings; 11 , female sitting on nest rim above young, and moving head left and right; 12 , after female leaves, small young remain low in nest; 13, young with head and body raised, looks after female when she flies from nest rim; 14, young with head and body raised when female arrives. 
pointing the bill up as if looking at something above her (fig. 6) or downward (fig. 7). Several times, the incubating female watched passing insects or even pecked or left to hover and eat one (fig. 8). She sometimes ejected feces, preened (fig. 9), scratched her head with her foot over the wing, stretched the wings, or turned on the nest.

The longest periods on the nest were 50-56 min ( 5 cases), 4 being midday on the 30 th and the other midday on the 29th. There were 6 cases of $41-49 \mathrm{~min}, 9$ of $31-39,16$ of 21-28, 32 of 11-20, 42 of 3-10 and 48 of 2 min or less, these often being during building activity. Periods off the nest were seldom over $15 \mathrm{~min}$ ( 7 cases, one being 32 min at 15 h 32 min on Oct 31 ); $11-15$ min were 15 cases; $6-10$ min were $48 ; 5$ min in 19 cases; $3-4$ in 12 cases; $0.5-2$ in 60 cases, mostly when bringing material. She was on the nest 61.5 to $80.2 \%$ of the day ( $31 \mathrm{Oct}, 1 \mathrm{Nov}$ ) for a total of $72.3 \%$ of $56 \mathrm{~h} 10 \mathrm{~min}$ watched. During the day, she was on the nest slightly less $6-8 \mathrm{~h}$ and $16-18 \mathrm{~h}$ than at midday (fig. 15).

The female seldom called while leaving and arriving at the nest during incubation but, after feeding young was noticed for the first time ( 5 Nov, 8 h 56 min), she usually arrived and left the nest with "tri-i-i" or longer calls. The incubating female champed the bill 3 times, protruded the tongue several times, and looked about a lot, just before leaving the nest (11 h $11 \mathrm{~min}, 24$ Oct, fig. 5). Often she would fly east and return from the east, but could fly north and return from the east or northwest.

Away from the nest, she sometimes preened, visited flowers, or pecked insects from foliage or bricks. Once she came back to a often used perch in a "sibipiruna" (Caesalpinea peltophoroides Benth., Leguminoseae) across the road (16 h $26 \mathrm{~min}, 31 \mathrm{Oct}$ ), preened on a dry horizontal branch $0.3 \mathrm{~cm}$ diameter and $3.5 \mathrm{~m}$ up: she preened the right wing, then the breast after a pause; her body feathers were fluffed. Two minutes later she raised the right wing and preened under it from behind, turning the head; she then preened the left wing, shook both wings as she opened the tail widely, and closed it again. She was partly in the sun. She preened the breast again, then both sides of the breast.

Frequent scratching while sitting (also in A. fimbriata, after HAVERSCHMIDT, 1952) may be due to blood-feeding mites (Acari) which may interfere with development of young, as reported by Alves (1997) in Riparia riparia (L., 1758) nestlings. Sheltered nests in buildings often present mites during nesting, as in Chlorostilbon aureoventris, Eupetomena macroura (Trochilidae), Zonotrichia capensis (Emberizidae), and Notiochelidon cyanoleuca (Vieillot,1817) (Hirundinidae) (Oniki, pers. obs.).

Nestlings. The first young hatched 5 Nov and, the second by the next day. The first young left between $16 \mathrm{~h} 30 \mathrm{~min}$ on $23 \mathrm{Nov}$ and $8 \mathrm{~h} 57 \mathrm{~min}$ on $24 \mathrm{Nov}$; one day later ( $6 \mathrm{~h}$ $52 \mathrm{~min}, 25 \mathrm{Nov}$ ) both had left the nest. Thus, young stayed in the nest 19 days.

RUSCHI $(1949,1982)$ mentioned 23 days as the time young stay in the nest, without noting what nest was studied. GRANTSAU (1988) also reported 23 days, perhaps following Ruschi. Other records by Ruschi have been strongly criticized (VANZOLINI, 1999). HAVERSCHMIDT (1952) noted 20 days for the related $A$. fimbriata. Further studies may be necessary to determine if nestling periods ever exceed 20 days in these species.

The female brooded tiny young regularly (5-7 Nov), but only once six days later ( 3 min stay on $13 \mathrm{Nov}$ ) and not thereafter. However, the longest brooding periods (5-7 Nov) were only $22-30 \mathrm{~min}$ ( 9 cases), 11-20 $\mathrm{min}$ (26 cases) and 3-10 $\mathrm{min}$ (36) being common; several visits of $2 \mathrm{~min}(10)$ and 1 (5, including 2 cases when she only fed, on the 7 th) were recorded. Intervals off the nest (5-7 Nov) were much as during incubation, 3 cases of 22- 
30 min, 13 cases of $11-16,38$ cases of $3-10,8$ cases of $1-2$ and 21 of brief intervals. Percent of the time brooding was about normal ( $70.9 \%$ ) with one young (5 Nov morning), dropped to $60.4 \%$ (6-7 Nov), and was $0.06 \%$ later (13 Nov). She was on the nest more $6-10 \mathrm{~h}$ than later in the day (fig. 15), perhaps because the air was less warm earlier. Late in nesting, she was not on the nest in the evenings (17 Nov on), though she went on the nest for the night when young were small ( 6 and 7 Nov). Lack of night brooding later, a common behavior in hummingbirds, may reflect small nest size and lack of space for the female to sit.

Fifty-three visits (13-21 Nov) were 16-91 min apart ( $X=40.7)$; records of 76,79 and $91 \mathrm{~min}$ were about $13 \mathrm{~h}$ on 3 days, while one of 16 min was early 20 November. Feedings were 1 or 2 per hour watched, being 1.7 per hour $10-12 \mathrm{~h}$ and dropping to 1.1 per hour 14-16 $\mathrm{h}$, then rising (fig. 15).

She occasionally flew to hover and peck an insect off leaves or vines before returning to the nest, but often got insects and returned to brood without feeding young. At times, she visited nearby flowers of Agapanthus cf. africanus L. (Liliaceae), Hemerocallis sp. (Liliaceae) or Petrea volubilis L., Clerodendron cf. thomsonae Balfour (both Verbenaceae) before returning to feed the young; in these cases she transferred nectar to young. Often she preened, spread her tail, or stretched, on favorite perches in shrubs not far from the nest, as if not pressed for time or food.

When cats were nearby (early $21 \mathrm{Nov}$ ), the female stayed away over $63 \mathrm{~min}$, chattering "chi-i-i," from a frequently-used perch in a nearby guava tree, finally preening and sunning a bit. She later attacked a Molothrus bonariensis female nearby investigating a Zonotrichia capensis (Müller, 1776) possible nest. On other days, she had attacked a Zonotrichia and a Thraupis sayaca (L., 1766) near the nest; occasionally disputes with passing Amazilia lactea were noted, but not with other hummingbirds. She fled when a person or cat passed on other days.

She fed the young after sitting on the nest edge (fig. 11), never while hovering. She usually looked about briefly and fed both young, at times returning one or more times to feed the first young, pumping the bill down into each young gape. Early in the nestling period, she ate small fecal sacs from the bottom of the nest and settled, after feeding. With only one young ( $5 \mathrm{Nov}$ ), she occasionally interrupted brooding, rose, and poked the bill down into the nest; on several visits (that day and 6-7 Nov) she did not feed, just sat

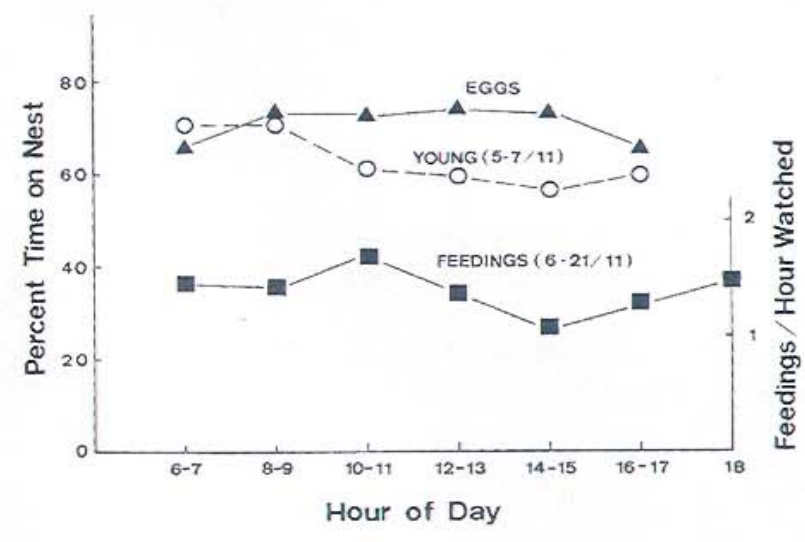

Fig. 15. Amazilia lactea brooding at different hours with eggs or young, and feedings per hour. on the nest. She could stretch the wings or defecate as she sat, or turn.

When 11-12 days old (17 Nov) young had their eyes open and pinfeathers had started to open on wings. Nestlings 15-16 days old (20 Nov) were seen ejecting feces for the first time, and leaves around the nest were spotted with black dots. On this date, one young was exercising the wings, rising up slightly above the nest rim (fig. 10). Young 15-16 days old (21 Nov) were exercising the wings, moving constantly in the nest; the base of the bill was pinkish, but the tip blackish. When the female was 
absent, young sat so low that only tips of head and bill were visible (fig. 12); they were higher on the nest when the female was flying around visiting nearby Clerodendron sp. flowers, when she flew from the nest rim (fig. 13), or when she arrived (fig. 14). Exercising or sitting up mainly when the female is present to keep the lookout may avoid predation. Young of this nest were not infested by Diptera botflies (Philornis sp.), unlike nestlings of Chlorostilbon aureoventris and Eupetomena macroura.

Ants wandering on nearby vines may have been attracted to the nest by feces, especially after young started to defecate outside, soiling nearby leaves. It could be that ants had to be removed by the female because of danger to the nestlings.

We tried to raise well-feathered motherless young at home ( 2 separate young of Eupetomena macroura and a nest with 2 young of Chlorostilbon aureoventris) and they fed on insects and sugar water but remained immobile and did not exercise the wings. Eupetomena young became flat-chested with lack of exercise, protein or muscle development (Oniki, pers. obs.). Perhaps young hummingbirds need the presence of the female to feel secure enough to preen actively or exercise wings, as we found also in Lipaugus lanioides (Lesson, 1844) (Cotinginae) (WILLIS \& ONIKI, 1998).

Other Nests. E. Willis found one bird sitting on a nest at $5.5 \mathrm{~m}$ in the Horto Florestal of Rio Claro on 23 Feb 1984; other single birds were carrying cat-tail down there on 18 April 1994 and building $3 \mathrm{~m}$ up at Fazenda Santa Genebra, Campinas on 8 Aug 1976. He also found one incubating $4 \mathrm{~m}$ up on a vine, 5 Nov 1976, at Fazenda Barreiro Rico in Anhembi. Apparently the species nests much of the year.

Acknowledgments. To Conselho Nacional de Desenvolvimento Tecnológico e Científico (CNPq) and the Universidade Estadual Paulista (UNESP) for support. Publication $n^{\circ} .12$ of the Instituto de Estudos da Natureza, Rio Claro.

\section{REFERENCES}

Alves, M. A. S. 1997. Effects of ectoparasites on Sand Martin Riparia riparia nestlings. Ibis, London, 139:4496.

Grantsau, R. 1988. Os Beija-flores do Brasil. Rio de Janeiro, Expressão e Cultura. 233p.

HAVERSCHMid, F. 1952. Notes on the life history of Amazilia fimbriata in Surinam. Wilson Bull., Lawrence, 64:69-79.

Ihering, H. Von. 1900. Catálogo crítico-comparativo dos ninhos e ovos das aves do Brasil. Revta Mus. paulista São Paulo, São Paulo, 4:191-300.

Niethammer, G. 1953. Zur Vögelwelt Boliviens. Bonn. zool. Beitr., Bonn, 4:195-303.

ONIKI, Y. \& ANTUNES, A. Z. 1998. On two nests of the Glittering-bellied Emerald Chlorostilbon aureoventris (Trochilidae). Ornitologia Neotrop., Montreal, 9:71-76.

Ruschi, A. 1949. Ninhos e ovos dos Trochilídeos. Bolm Mus. Biol. Prof. Mello Leitão, Sér. Biol., Santa Teresa, (4):1-65.

1982. Beija-flores do Estado do Espírito Santo. Rio de Janeiro, Rios. 263p.

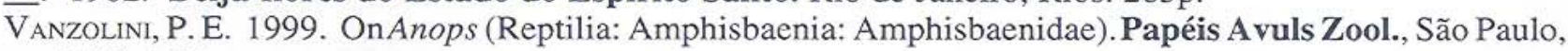
41(1):1-37.

Willis, E. O. \& Oniki, Y. 1998. One-parent nesting in Cinnamon-vented Pihas (Lipaugus lanioides, Cotinginae, Tyrannidae). Ornitologia Neotrop., Montreal, 9:129-159.

Recebido em 29.11.1999; aceito em 10.03.2000. 